Article

\title{
Reframing Catholic Theological Ethics from a Scotistic Perspective
}

\author{
Nenad Polgar \\ Faculty of Catholic Theology, University of Vienna, Schenkenstraße 8-10, 1010 Vienna, Austria; \\ nenad.polgar@univie.ac.at
}

Received: 17 August 2017; Accepted: 16 September 2017; Published: 21 September 2017

\begin{abstract}
The article engages with Joseph Selling's most recent publication Reframing Catholic Theological Ethics in which he invites theological ethicists to re-think the post-Tridentine development of theological ethics by noting its methodological deficiencies, misrepresentation of sources, and an insufficient interest in the most fundamental question: What is it that we are trying to achieve in our moral lives in the first place? In order to re-orient the discipline, Selling proposes a new reading of Thomas Aquinas' Treatise on Human Acts (ST I-II, 1-21), but the present author argues that this might not be enough, given the debate within the discipline on how Aquinas' text ought to be interpreted. Hence, the author proposes an alternative route to 'reframing Catholic theological ethics' via the works of John Duns Scotus and explores his ethical ideas that might be pertinent for such a project. The main focus of the article is a reflection on Scotus' 'case study' of marriage and bigamy in the Old Testament that justifies drawing a parallel between his work and Selling's attempt to reframe Catholic theological ethics.
\end{abstract}

Keywords: John Duns Scotus; theological ethics; marriage and bigamy; Thomas Aquinas; recta ratio

\section{Introduction}

In his most recent publication Reframing Catholic Theological Ethics, Joseph Selling invites us to re-think the post-Tridentine development of theological ethics. He argues that the excessive focus on the object of the act and a specific understanding of natural law have deformed the discipline and turned it into a confessional tool, rather than the specifically Christian way of engaging with and reflecting on moral life. Although he argues that such an approach was understandable and, perhaps, even necessary within that particular period of Church history, continuous insistence on it, even after the Second Vatican Council, is highly problematic. Namely, it misrepresents its own claimed sources (most notably, Thomas Aquinas) and misses the crucial insights that these tried to convey, is entirely oblivious of underlying methodological issues, and brought the whole discipline to a deadlock, to mention just a few (Selling 2016, pp. 1-12). In the effort to correct or, at least, prompt us to reflect on current deficiencies in the discipline of theological ethics, Joseph Selling proposes a different reading of Aquinas' Treatise on Human Acts (Summa theologiae I-II, qq. 1-21); one that would show a greater awareness of Thomas' overall aretaic approach and raise questions such as-what is it that we are trying to achieve in our moral lives in the first place (Selling 2016, chp. 3)?

Although there is much to commend in Selling's approach in general, one might expect that the reaction to his call within the professional community will depend very much on whether his interpretation of Aquinas will be accepted or at least engaged with. Unfortunately, Richard McCormick's comment that one can get almost anything out of Aquinas if enough texts are adduced (McCormick 1981, p. 67), works against Selling's interpretation, precisely because of the longstanding influence of manuals of moral theology. A possible way to deal with this problem would be to expand the basis on which Selling's argument rests and offer alternative routes to "reframing Catholic 
theological ethics". In that effort, this paper will briefly explore ethically relevant concepts of another medieval giant of theological thought, who has been relegated to the margins of the theological enterprise in manuals of moral theology, John Duns Scotus. More specifically, the goal of the paper is to try to justify using Scotus as a source for reframing theological ethics by offering a short introduction into his ethical thought and then reflecting on how he dealt with the concrete issue of marriage and bigamy. This will, finally, allow some parallels between Selling's and Scotus' approach to moral reasoning to be drawn-(1) the notion of premoral and moral good and evil; (2) the primary importance of the end in the specification and evaluation of moral acts; and (3) the (ir)relevancy of the concept of intrinsic evil. If demonstrated, the convergence between the two authors ought to recommend the need for a deeper engagement with Scotus' writings within the contemporary discipline of Catholic theological ethics as an inspiration for its renewal and a way around endless debates on the right interpretation of Aquinas.

\section{Why Scotus?}

There is much to commend Scotus' theology as a source for reframing Catholic theological ethics, but before I turn to it, I would like to comment briefly on his historical significance in relation to such a project. At first sight, it seems that Scotus' historical (in)significance argues against enlisting him as a source for reframing Catholic theological ethics. Namely, despite his early popularity which lasted until the seventeenth century and, according to some scholars, spawned a theological school that was perhaps even more influential than the Thomistic school (Osborne 2014, pp. xiv-xv), the more recent period has not been so kind to Scotus. This, of course, was due to two reasons; (1) a general impression that Scotus was an intellectual predecessor of William of Ockham ${ }^{1}$; and (2) the rise of and official support that Thomism received, especially after the promulgation of the encyclical Aeterni patris of Leo XIII (Leo 1879) ${ }^{2}$. Hence, one might argue, for better or for worse, Scotus has fallen out of favour with the more recent developments in moral theology and Aquinas carried the day.

Despite this unfortunate development, in my opinion, Scotus should not be treated as irrelevant or reduced to a theological footnote. On the contrary, this puts him and his theology in a unique position to contribute significantly to the renewal of theological ethics. As I pointed out earlier, his diminished authority is precisely what spared him Aquinas' fate of being re-interpreted by the manualists. True, theologians like Thomas de Vio (Cardinal Cajetan) and Francisco Suarez commented on and interpreted Scotus, but the scope of this is hardly comparable with the attention Aquinas received. For this reason, it is much easier and it invokes much less controversy to go back to his texts.

On the other hand, if there is any merit to Selling's position, it indicates that Thomas' understanding of ethics was disfigured and misunderstood during the manualist period and, therefore, one could argue that Thomas was the dominant authority during that period in name only. In other words, what was authoritative was a later interpretation of Thomas, while his original contribution has been pushed to the side, as much as Scotus' was, albeit for different reasons. Nevertheless, this will still cause significant, perhaps insurmountable, difficulties for any contemporary attempt at a retrieval of Thomas' actual position in Summa theologiae I-II, qq. 1-21 and this is why turning to Scotus can be an easier route for the renewal of theological ethics or at the very least, Selling might find in him a valuable ally for his project.

1 Scotus' decline was, in my opinion, more a result of this general impression than respective differences between him and Aquinas, which is not to deny that there were differences between them. This general impression was that Scotus was a proponent of voluntarism, while Aquinas was a proponent of intellectualism and the latter was more in line with the Catholic understanding of morality. Although this observation rests on how Scotus was treated by theologians of the Second Scholasticism and the manual tradition within the Catholic Church, the Radical Orthodoxy movement has further fueled this skepticism towards Scotus in the recent decades. Cf. (Pickstock 2005, pp. 563-69).

2 The subtitle of the encyclical letter, On the Restoration of Christian Philosophy in Catholic Schools in the Spirit of the Angelic Doctor, St. Thomas Aquinas, is very suggestive in terms of its aim. 


\section{Scotus' Meta-Ethics in a Nutshell}

As a preliminary note, it is important to point out that on the meta-ethical level, Scotus aims at preserving both divine reason and freedom against what might be called the view of ancient Greek necessitarianism, i.e., the notion that everything truly real and worth knowing proceeds from the first necessary cause and, therefore, true knowledge consists of necessary truths, not contingent ones (Jaczn et al. 1994, pp. 18-19). Aquinas also subscribed to this view, but modified it in order to take into account the Christian doctrine of creation (Aquinas 1955-1957, b. II, chp. 30) ${ }^{3}$. Scotus, however, went a step further and posited that God did not only decide freely to create the world, but also decided freely what kind of world he will create, among many different possibilities imaginable (Jaczn et al. 1994, p. 90; Lectura b. 1, dist. 39, q. 5) ${ }^{4}$. This position introduces contingency into creation (and, implicitly, into the moral order) and ascribes it to the first cause, God. ${ }^{5}$

One of the consequences of this position is that Scotus' concept of natural law is more complex then Aquinas', insofar as it takes into account the contingency of the world and disassociates the goals and values we pursue from the ultimate end, the beatific vision of God. Some authors refer to this as Scotus' "denaturalisation" of the natural law, where the order of the precepts of the law of nature does

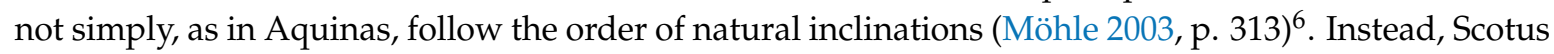
posits the distinction between natural law in the strict sense and natural law in the extended sense. The former refers to those precepts that are necessarily true, while the latter refers to those precepts which can be shown to be in harmony with the former, but not necessarily true. To illustrate this point, Scotus refers to the Decalogue and claims that only the commandments about loving God (first tablet) belong to the natural law in the strict sense, while all other commandments belong to the natural law in the extended sense (Wolter and Frank 1997, p. 195; Ordinatio b. IV, dist. 17). This will have far reaching consequences for his whole ethical theory. Furthermore, since Scotus refuses "a matrix in which our existence is completely fixed" (Jaczn et al. 1994, p. 22) and moral absolutes associated with commandments of the second tablet of the Decalogue, his ethical thought further substantiates Selling's call to rethink moral methodology.

\section{Marriage and Bigamy}

Perhaps the most illustrative example of the application of Scotus' ethical theory is his treatment of the Old Testament cases of divine dispensations. One such case concerns marriage and bigamy, and he asks the question: "So far as the Mosaic law or the law of nature is concerned, was bigamy ever licit or, were the patriarch of old allowed to have several wives joined in the bonds of matrimony?" (Wolter and Frank 1997, p. 208; Ordinatio b. IV, dist. 33, q. 1) In the continuation, Scotus first aims to establish the purposes of marriage and the status of the precept related to it as being a precept of natural law in the extended sense, in order to demonstrate that this issue qualifies as a candidate for

3 References to Aquinas' translated works in the main text are specified by the modern edition, followed by details of the original work (title, book (b.), distinction (dist.), question (q.), or chapter (chp.)).

4 References to Scotus' translated works in the main text are specified by the modern edition, followed by details of the original work (title, book (b.), distinction (dist.), question (q.), and article (a.)).

5 Hence, one could say that Aquinas tried to justify the doctrine of creation within the frame of ancient Greek necessitarianism by introducing into it the act of creation, while Scotus found the view entirely incompatible with the doctrine of creation and developed an alternative ontology.

6 In other words, Scotus does not follow the Thomistic understanding that links the eternal law with creation (including "nature" and natural inclinations) through the notion of natural law as a rational participation in the eternal law. In fact, the whole notion of eternal law has no role in his ethical system. Instead, what belongs to the natural law (in the strict sense) is determined on the basis of the content of a given commandment, i.e., if it is conceptually necessary that the commandment be valid. The "conceptually necessary", in this context, means necessary for the attainment of the ultimate end (the beatific vision) and this can be said only of those commandments that express self-evident principles (such as the first and the second commandment). Only such commandments prescribe goodness that cannot be repudiated without also repudiating the ultimate end. Cf. (Möhle 2003, pp. 314-16). 
divine dispensation. ${ }^{7}$ Following his interpretation of the Scriptures, Scotus identifies two purposes of marriage: the primary being procreation and the education of children, and the secondary being the avoidance of immorality. Furthermore, the principle underlying both of these purposes is the principle of justice.

Scotus was well aware that certain Old Testament patriarchs had more than one wife and, hence, he needed to provide an explanation as to whether they were given a divine dispensation as they practiced polygamy, and if so, what happened with the precept of natural law in such instances. His explanation builds on the notion of commutative justice, that for some, he argues, "requires quantitative equality not only proportional equity" (Wolter and Frank 1997, p. 185; Ordinatio b. IV, dist. 46). If this is true, he proceeds, then there is some imbalance in every marriage since "the male body is of more value than the female, for the same man could fecundate several women during the time it takes for the same woman to conceive through men" (Wolter and Frank 1997, p. 209; Ordinatio b.IV, dist. 33, q. 1). Consequently, if one judged marriage only on the basis of its primary purpose, there would be no reason to hold bigamy immoral. As opposed to this, when it comes to the secondary purpose of marriage (avoidance of immorality, i.e., fornication), male and female bodies are of equal value and, therefore, demand "one-to-one exchange of bodies" in order to satisfy justice.

This would seem to put the two purposes of marriage in opposition to each other and lead to the conclusion that since the primary purpose is, by definition, more important, it alone should be followed, even if the secondary one needs to be sacrificed. However, at this point Scotus introduces the will of the legislator (in this case, God) and argues: "Although some things belong to their owners, still what determines whether such and such an exchange is licit depends on the legislator, and this is true even more so as regards the mutual bodily exchange in the presence of a legislator who is God" (Wolter and Frank 1997, p. 209; Ordinatio b. IV, dist. 33, q. 1). Since, he continues, God has decreed that marriage should be between one man and one woman (the sixth commandment), what is just when it comes to marriage is clear.

Despite recognising the will of the legislator, Scotus does not deny the previous conclusion that on the basis of the primary purpose of marriage, bigamy is as reasonably acceptable as monogamy, if not more so. However, since the divine will has decreed otherwise in this case, it is impossible to make the case for the morality of bigamy without introducing the concept of divine dispensation, understood as revocation of the relevant precept in a particular case, and this is precisely what happened in the case of the Old Testament patriarchs. Namely, as Scotus explains, this happened in a situation in which the number of those who worship God was fairly small, and in order to increase their number, patriarchs were given a divine dispensation to marry more than one woman.

Interestingly, Scotus is not content with simply pointing towards the divine will that makes arbitrary decisions when it comes to the precepts of natural law in the extended sense (or precepts of divine positive law). In other words, it is not enough for him to point simply towards the divine will when answering the question why God decreed one way instead of the other when both options seem reasonable and possible. This is noticeable already in the fact that he provides a reason why God would give such a dispensation to the Old Testament patriarchs at all and, more importantly, he engages in a longer explanation in order to show the rational underpinnings of this divine intervention. Namely, he claims that "when there are two reasons why something is ordered, one the principal purpose, the (Wolter and Frank 1997, p. 210; Ordinatio b. IV, dist. 33, q. 1) ${ }^{8}$. Hence, one might imagine a situation

7 Since the issue of marriage and bigamy is related to the sixth commandment (the second tablet), it is obvious that it does not concern the natural law in the strict sense or goodness that is necessarily linked to the attainment of the ultimate end.

8 One of the anonymous reviewers of this article has argued that Scotus' way of reasoning through the problem of the relationship between marriage and bigamy does not seem to provide a convincing solution, since it seems to suggest that the only way of achieving one purpose of marriage is to go directly against the other, which would then make the natural law seem arbitrary. I believe that this critique stands only if the natural teloi of marriage are understood as principles that need to be followed or accommodated in any morally acceptable solution. As far as I understood Scotus, the two purposes of marriage should rather be understood as inconclusive indications of what would be a rational thing to do in this area of 
where a war or an illness were to decimate the human population to such an extent that giving priority to the primary purpose of marriage would become just on the part of the contract and contracting parties; although, Scotus points out, "the complete justice" would still demand some kind of divine dispensation. Furthermore, Scotus does not exclude the possibility that such might be the case in the future and he even envisions that in such a situation divine dispensation could "then occur and be revealed in a special way to the Church" (Wolter and Frank 1997, p. 210; Ordinatio b. IV, dist. 33, q. 1) .

Related to this, Scotus rejects the "exception" explanation of divine dispensations by pointing to the principles of non-contradiction and internal coherence. ${ }^{10}$ An added effect of these principles on Scotus' ethical theory in general and his treatment of divine dispensations in particular is that they allow, as we saw in the case of bigamy, a certain weighting of goods, depending on circumstances in which a precept or a commandment is to be applied. In other words, Scotus is not content with saying that a divine dispensation simply occurred in some instances, but aims at an explanation of why it occurred and this explanation reveals a rational procedure underlying a divine dispensation.

\section{Further Issues}

There are two issues that emerge in relation to this example. The first has to do with Scotus' attempt to find a balance between what is just according to reason and what is just according to the revealed divine will. Now these two coincide in Scotus' example to such an extent that he is fully justified in claiming that "where creatures are concerned he [God] is debtor rather to his generosity, in the sense that he gives creatures what their nature demands" (Wolter and Frank 1997, p. 190; Ordinatio b. IV, dist. 46). However, suppose that in some hypothetical case in the future (due to a nuclear war or a globally devastating disease) humankind were to diminish in number to such an extent that bigamy becomes simply necessary for the human species to survive. This would then satisfy Scotus' condition under which the primary purpose of marriage should be given the upper hand in determining what is the just (and, therefore, moral) thing to do, not to mention that the survival of the human species would depend on timely recognition of the special circumstances. Now, while Scotus would confirm that giving priority to the primary purpose of marriage in such circumstances is a just thing to do, he still demands divine dispensation in each particular case as a necessary requirement

life (and this is because there is no necessary relation between natural teloi and the ultimate end of human life for Scotus). They are inconclusive indications because the most Scotus can say is that there are rationally sound reasons to pursue only the primary purpose of marriage, as well as to pursue both primary and secondary purpose (although the latter solution already militates against the primary end to an extent, since one is not going to have as many children as one could by pursuing only the primary purpose of marriage). In order to turn these inconclusive indications into a rationally compelling argument (in the sense of recta ratio), circumstances need to be considered (and the argument needs to be sanctioned by the divine will). Nevertheless, since these inconclusive indications are both rationally sound, none of the possible solutions would make natural laws related to them internally incoherent (in the sense of irrational or incomprehensible).

9 This is exactly opposite of the claim made by Ansgar Santogrossi who tried to summarise Scotus' position on dispensations by formulating a contemporary Scotistic gloss: “A contemporary Scotistic gloss on the pope's [John Paul II] words might run: given the categorical, universal character of St. Paul's condemnation of certain acts falling under the second table of the Decalogue, the closure of revelation with the death of the last apostle, and the obvious thrust of the Veritatis splendor, it can be stated that it will never be licit to act against the divine precept 'till heaven and earth pass away', regardless of how the Old Testament loci for dispensations from those precepts should be interpreted; nevertheless in the last analysis this is because God has graciously and contingently willed it so" (Santogrossi 1994, p. 326). Although I can agree with Santogrossi that, according to Scotus, God's gracious and contingent decision of the will is certainly responsible for the OT dispensations, Scotus is quite clear that such dispensations both occurred and can still occur. Hence, Santogrossi's limitation of the scope of the divine contingent will, introduced in order to bring it in line with Veritatis splendor, is clearly misplaced. Apart from that, if the possibility of dispensing from precepts of natural law in the extended sense is a prerogative of God's gracious and contingent will, then denying this prerogative is an expression of hubris that reserves for itself another prerogative of knowing better how God's graciousness should be exercised and, naturally, it should never be exercised in opposition to what is expected of it.

10 The reason why Scotus rejects the "exception" explanation of divine dispensation, as Möhle explains, consists in the fact that he holds the principles of non-contradiction and coherence as valid, even when it comes to what God can do, due to his absolute power. From these two, Scotus argues that God cannot order the world in such a way that the precepts of that ordering would contradict each other. Even more, these precepts have to constitute a coherent whole. Hence, if the "exception" explanation of divine dispensations were to be valid, then God could simply disregard these two principles, while decisions of his will would have an arbitrary character. Cf. (Möhle 2003, p. 321). 
for what he calls "complete justice". But, suppose that human species or, at least, the community of believers does not receive such dispensation, because, as Scotus himself claims, "in truth nothing outside of God can be said to be definitely just [ . . ; ] where a creature is concerned, God is just only in relationship to his first justice, namely, because such a creature has been actually willed by the divine will" (Wolter and Frank 1997, p. 190; Ordinatio b. IV, dist. 46).

In my opinion, this passage and Scotus' insistence on the freedom of the divine will argues in favour of the possibility that in the above hypothetical case, the human species might not receive the needed divine dispensation or, in a milder form of the argument, it might not recognise it. If this is possible, then one would have to conclude that, in the first case (of not receiving divine dispensation), what is just according to reason, namely, preservation of the human species, is at the same time unjust according to the divine will and vice versa. In other words, one would have to conclude that in the perspective of "complete justice" it is morally wrong for the human species to do what they deem necessary and reasonable for their own preservation in the given circumstances, which seems counterintuitive.

On the other hand, the second case (of not recognising divine dispensation) raises a different issue of the form in which the divine dispensation should appear. Building on the Old Testament cases of divine dispensations, Scotus somewhat predisposes us to think of some kind of supernatural intervention, but should this necessarily be so? Is it not also imaginable to think of divine dispensation becoming manifest through dictates of right reason, especially in such an extreme case? Of course, this would also mean that in such a situation ethicists could not aim for certain knowledge, since, according to Scotus, one is not dealing here with necessary truths, but with contingent ones that depend on decisions of the divine will. However, if this is the case, then a divine dispensation would only confirm the insight gained through reason and, therefore, make it certain, but the issue remains whether such certainty is absolutely necessary for moral decision making and moral action. A renowned Scotistic scholar, Allan Wolter, would agree with this and argue in favour of the quasi-sufficiency of right reason:

Even the sort of dispensations Scotus sees God making [ ... ] are always in accord with right reason, and are something the human mind did figure out, or might have if emotions did not blind one's reason. For they concern such things as are good for man [sic] in relation to his fellowman, where there is a hierarchy of values involved, and where to obtain the principal value, certain aspects of lesser value may have to be sacrificed, in view of a less than ideal environmental situation. (Wolter and Frank 1997, pp. 26-27)

The second issue related to the above example points towards the not-so-hypothetical case of over-population on the planet or in some regions in the world. If one were to continue to follow the same logic as I used in my analysis of the previous issue, then one would have to conclude that this drastic change in circumstances should also reflect on how one applies Scotus' purposes of marriage. In other words, if the secondary purpose of marriage has to be sacrificed in a situation where the survival of the species might well depend on giving priority to the primary purpose of marriage, should the reverse not also hold when the population has increased to such an extent that its numbers threaten its own survival and make the possibility of a total war for the world's resources quite imaginable? Of course, apart from giving some kind of priority to the secondary purpose of marriage (avoidance of fornication or, more positively, companionship or love), this argument does not resolve entirely what God's will in such a case might be (celibacy? natural family planning? contraception?), but it certainly shows the direction in which recta ratio, at least as envisioned by Scotus, would point (Wolter and Frank 1997, p. 72). ${ }^{11}$ Furthermore, these two extreme cases of underpopulation and overpopulation suggest that Scotus is content with postulating the existence of only one absolute

11 In these issues related to the example of bigamy, I followed Scotus' distinction between primary and secondary purpose of marriage in order to see where his reasoning would take us when it comes to various situations and to demonstrate 
value, God himself and how we relate to him, while being aware that human values (and how they are realised in concrete norms, behaviour, and acts) do not (and does not) suffer absolute and universal solutions, unless one is willing to sacrifice recta ratio.

Being true to the recta ratio, on the other hand, demands bringing together the first principle of praxis, the conclusions of moral science, and the specific conditions under which the act is considered. Apart from the first principle of praxis that already grounds reasons' deliberations in objective reality, the notions of "seeing" and "hearing" that Scotus uses in this context, also hint at something objective that is present and that needs to be recognised and taken into consideration by the agent (Ingham and Dreyer 2004, pp. 176-77). These, of course, refer to goods that are a part of objective reality and dividable into useful goods (bonum utile) and goods of value (bonum honestum) that correspond to the affection for the advantageous and the affection for justice, respectively. Starting from these, rational judgment will also have to take into consideration other conditions (such as, whether the act is done for right reason, at the right time and place, in the right manner, and as a prudential person would perform it) in order to satisfy the demand for objectivity. It is clear from this that Scotus' insistence on the primacy of recta ratio is not a flight into moral subjectivism, but an affirmation of the nature of moral reasoning that presupposes and takes into consideration objective reality (both necessary and contingent), while at the same time it escapes the naïve approach of reducing moral deliberations to deductive reasoning and instead likens it to aesthetic judgments.

\section{Conclusions}

Although a more detailed argument in favour of recruiting Scotus as a source for reframing Catholic theological ethics would demand an overview of his whole ethical theory, as well as an engagement with its finer details, even this short paper based on a particular issue he dealt with allows one to draw out some preliminary conclusions. In what follows, these preliminary conclusions will be presented in terms of the previously mentioned methodological points of convergence between Scotus and Selling: (1) the notion of premoral and moral good and evil, (2) the primary importance of the end in the specification and evaluation of moral acts, and (3) the (ir)relevancy of the concept of intrinsic evil. ${ }^{12}$

\subsection{The Notion of Premoral and Moral Good and Evil}

In order to make his argument that the presence of evil or a disvalue in a human act does not necessarily mean that the act is morally evil, Selling uses the distinction between premoral and moral good/evil and relates the former to Aquinas' notion of natural good/evil and the manualist notion of physical evil (Selling 2016, pp. 171-86). ${ }^{13}$ However, the counter-argument in this sense (for instance, from the proponents of the New Natural Law Theory) claims that one should never act directly against a basic good (Finnis 2011, pp. 118-24), and one of the reasons, I suspect, that lies behind the coherence of this claim is the previously mentioned close connection between the precepts of the law of nature and the order of natural inclinations that Aquinas posited.

that there is an underlying method to his reasoning. Of course, if we were to apply his method to contemporary Catholic teaching on marriage (that does not distinguish between primary and secondary ends of marriage, although it claims that the ends of marriage are inseparable), the results would be different.

12 In formulating these three points of convergence I am indebted to Thomas Shannon. Cf. (Shannon 1995, pp. 87-113).

13 By premoral evil Selling refers to those realities, specified descriptively, that are harmful to human beings (hence, -moral), but are not immediately morally determinative (hence, pre-), such as death, sickness, ignorance, etc. Similarly, premoral goods are those realities that are beneficial to human beings, but are not immediately morally determinative, such as health, nutrition, knowledge, etc. The notion of moral good/evil, on the other hand, always implies a reference to the human will intending how to bring about a certain end and choosing means to it. In this sense, Selling would argue that sometimes one can choose a premoral evil as a means of attaining a good end (for instance, punishing a criminal to attain justice in a society) and this kind of premoral evil does not make the whole act morally evil. However, he warns, "the manner or extent to which some evil may be attached to the moral event [ . . ] is not always straightforward". (Selling 2016, p. 181). 
I believe that this is a point where Scotus' approach can be of some use. Namely, the problem with erasing or disregarding the distinction between premoral and moral goods/evils in writings of some contemporary moral theologians is that (at least some) goods assume an almost absolute character. On the other hand, Scotus acknowledges the importance of the precepts of the second tablet of the Decalogue, since they are in harmony with the natural law in the strict sense and a part of the moral order that God established for this world, but refuses, as we saw in the example of marriage and bigamy, to treat them in an absolute way by proposing a universal, one-size-fits-all, short-circuited solution to ethical dilemmas, wherever these "absolute" values appear. This does not only mean that theoretically and metaphysically the moral order could have been different, it also means that his understanding of goods and how they constitute moral goods is more dynamic, since, as he claims: "The precepts of the second table contain no goodness such as is necessarily prescribed for attaining the goodness of the ultimate end, nor in what is forbidden is there such malice as would turn one away necessarily from the last end" (Wolter and Frank 1997, p. 277; Ordinatio b. 3, dist. 27). Apart from the implications that this position has for the role of recta ratio in moral reasoning, one could also argue that it is compatible with the distinction between premoral and moral goods, as well as with the human person being the standard for theological ethics, as Selling suggests (Selling 2016, chp. 5).

\subsection{The Primary Importance of the End in the Specification and Evaluation of Moral Acts}

Because of the later emphasis on the object of the act during the manualist period, Selling dedicates a good portion of his book to demonstrating the primary importance of the end in the specification and evaluation of human acts in Aquinas' Treatise on Human Acts (Selling 2016, pp. 62-82). This, again, is a contested point in contemporary theological ethics that often leads to endless discussions on how Aquinas should be interpreted. There is much less controversy, on the other hand, related to Scotus' treatment of this topic. First of all, Aquinas, Scotus, and Selling agree on the claim that the end takes precedence in the specification and evaluation of human acts, but Aquinas' explanation of the relation between the end and the object is convoluted and leaves room for contrary interpretations, as evidenced by the whole manualist tradition and the post-conciliar debates within the field of theological ethics.

Scotus' approach, on the other hand, is simpler, but perhaps more elegant. He first claims that the goodness of an act depends on whether it possesses "all that the agent's right reason declares must pertain to the act or the agent in acting" (Alluntis and Wolter 1975, p. 400; Quodlibet q. 18, a. 1) and the right reason judges this from the nature of the terms or from intellectual knowledge. Put differently, if one knows the nature of the agent, the power by which the agent acts, and has the essential notion of the act one is equipped to judge the appropriateness of particular acts. According to Scotus, this is done by first identifying the object of an act, which is identified with 'matter' (such as food being the object of the act of eating) or 'moral matter' (such as taking what belongs to another being the object of the act of theft). However, the object merely puts the act in the moral domain and opens it to further moral determination, which is done by considering the circumstances of the act. The most important and morally determinative circumstance is the end and, therefore, the most one could say about an act on the basis of the object alone is that it tends towards good or evil, but it is, strictly speaking, morally indifferent. Scotus clearly demonstrates this approach in his treatment of marriage and bigamy in which the importance of shifting circumstances and especially the end plays a determinative role in the ethical evaluation of the whole issue and the acts associated with it. ${ }^{14}$ As such, it ought to be

14 The end as a circumstance is the end of an agent, which could be any of the two goods associated (for Scotus) with marriage or both. His point (and mine in presenting and developing his point) is that one cannot exclude a priori any of these two (or three) possibilities as being always immoral, since circumstances might demand giving priority to one of the goods associated with marriage (provided a divine dispensation has also been given). Since these goods are both relative in relation to the ultimate end, they do not always have to be pursued by the will when one intends marriage (such as in the case of underpopulation (Scotus) or overpopulation (my deduction)). 
studied closer in order to determine its potential for reframing the issue of fontes moralitatis within contemporary theological ethics.

\subsection{The (Ir)Relevancy of the Concept of Intrinsic Evil}

At various points in his study, Selling argues that the notion of intrinsic evil ought to be eliminated from Catholic ethical discourse, since, as a product of an inaccurate manualist reading of Aquinas, it does not contribute anything to ethical discernment and is simply confusing as it generally leaves the impression that acts can be morally evaluated on the basis of an inadequate description (Selling 2016, pp. 162, 179, 200). Although this is contrary to Aquinas' way of thinking in Summa Theologiae I-II, there are still some places where he leaves the impression that some objects (i.e., what is done) can never be a part of a morally good act—such as in De malo, q. 2, aa. 3-4 and in Summa Theologiae I-II, q. 20. a. 2.

On the other hand, Scotus is quite clear on this point by allowing only one absolute intrinsic value, and that is God himself. ${ }^{15}$ Consequently, there is only one object that can never be a part of a morally good act, and that is hatred of God. Since the obligation to worship God is part of the natural law in the strict sense that expresses a necessary truth, not even God can make such knowledge false or give a dispensation from this obligation.

In that sense all other values are relative. In other words, they are a part of this current moral order, in harmony with the natural law in the strict sense, and, as such, willed by God for our good and conducive to our salvation. However, Scotus claims that it is possible "for me to will that my neighbour love God and nevertheless not will that he preserves corporeal life or conjugal fidelity" (Wolter and Frank 1997, p. 285; Ordinatio b. III, dist. 27), while his treatment of marriage and bigamy, as well as the other Old Testament dispensations, illustrates this point as a "fact", i.e., as (moral) events that took place.

\subsection{Scotus' Contemporary Significance}

One of the main achievements of Selling's book Reframing Catholic Theological Ethics is that it appeals to a reader's ethical imagination by posing the question-what is it that we are trying to achieve in our moral lives in the first place? Seen from this perspective, the manual tradition's focus on acts, objects, and moral pathology (sins) is revealed as one possible answer to this question within the Catholic tradition and not the Tradition itself. Selling suggests further that returning to Aquinas' text in Summa theologiae offers another possible answer and an exploration of Scotus' thought, attempted in this article, promises yet another answer within that same tradition.

Despite a contrary judgement found within the more recent history of the discipline of theological ethics that dismissed Scotus' ethical thought as highly suspicious in terms of its compatibility with the Catholic tradition, contemporary engagement with his thought demonstrated that Scotus is closer to Aquinas on some key points than Aquinas' later commentators (Salzman 1995, pp. 375-88). This is certainly true when it comes to what was later called fontes moralitatis (object, end, and circumstances) and the insistence of both Scotus and Aquinas that the end takes precedence in the specification of human acts. From this point, as the article showed, Scotus develops his thought in a different direction than Aquinas. However, an urgent task of rethinking the ends of our ethical striving within

15 By using a case study of lying Richard Cross has argued that Scotus is in fact a proponent of the concept of intrinsically evil acts as those acts that are morally wrong on the basis of their object. According to Cross, Scotus' list of such acts would not include only hatred of God, but also lying, murder, theft, and adultery. It is impossible to evaluate Cross' carefully argued claims within the frame of this article, since one would first have to discuss how Scotus and then Cross understand objects of the abovementioned acts and only then proceed to engage with the claims Cross has made. Another problem with the case study of lying is that Scotus seemed to have stopped somewhere in the middle between, on the one hand, what he encountered in the tradition (especially Augustinian tradition) and other medieval theologians when it comes to lying and, on the other hand, bringing his reflection on lying more in line with the more general direction of his own thought that goes beyond the natural teleology approach. This is what makes Cross' claim debatable and Scotus' treatment of lying as, perhaps, not the most representative of his thought. Cf. (Cross 1997, pp. 48-76). 
contemporary theological ethics and letting go of the fascination with moral pathology, encounters in Scotus a challenging dialogical partner whose ideas can significantly expand the horizon of the discipline while keeping it firmly grounded in the tradition.

Conflicts of Interest: The author declares no conflict of interest. The founding sponsors had no role in the design of the study; in the collection, analyses, or interpretation of data; in the writing of the manuscript, and in the decision to publish the results.

\section{References}

Alluntis, Felix, and Allan B. Wolter. 1975. John Duns Scotus: God and Creatures: The Quodlibetal Questions. Washington: The Catholic University of America Press.

Aquinas, Thomas. 1955-1957. Summa contra gentiles. Available online: http://dhspriory.org/thomas/ ContraGentiles.htm (accessed on 26 April 2017).

Cross, Richard. 1997. Duns Scotus on Goodness, Justice, and what God Can Do. Journal of Theological Studies 48: 48-76. [CrossRef]

Finnis, John. 2011. Natural Law and Natural Rights. Oxford: Oxford University Press.

Ingham, Mary B., and Mechthild Dreyer. 2004. The Philosophical Vision of John Duns Scotus: An Introduction. Washington: Catholic University of America Press.

Jaczn, Antoon V., Henri Veldhuis, Aline H. Looman-Graaskamp, Eef Dekker, and Nico W. den Bok. 1994. John Duns Scotus: Contingency and Freedom: Lectura I 39. Dordrecht: Kluwer Academic Publishers.

Leo, XIII. 1879. Aeterni Patris. Available online: http://w2.vatican.va/content/leo-xiii/en/encyclicals/ documents/hf_l-xiii_enc_04081879_aeterni-patris.html (accessed on 26 April 2017).

McCormick, Richard A. 1981. Notes on Moral Theology 1965-1980. Washington: University Press of America.

Möhle, Hannes. 2003. Scotus's Theory of Natural Law. In The Cambridge Companion to Duns Scotus. Edited by Thomas Williams. Cambridge: Cambridge University Press, pp. 312-31.

Osborne, Thomas M. 2014. Human Action in Thomas Aquinas, John Duns Scotus \& William of Ockham. Washington: Catholic University of America Press.

Pickstock, Catherine. 2005. Duns Scotus: His Historical and Contemporary Significance. Modern Theology 21: 543-74. [CrossRef]

Salzman, Todd. 1995. Deontology and Teleology: An Investigation of the Normative Debate in Roman Catholic Moral Theology. Leuven: Leuven University Press.

Santogrossi, Ansgar. 1994. Scotus's Method in Ethics: Not to Play God-A Reply to Thomas Shannon. Theological Studies 55: 314-29. [CrossRef]

Selling, Joseph A. 2016. Reframing Catholic Theological Ethics. Oxford: Oxford University Press.

Shannon, Thomas A. 1995. The Ethical Theory of John Duns Scotus. Quincy: Franciscan Press.

Wolter, Allan B., and William A. Frank. 1997. Duns Scotus on the Will and Morality. Washington: The Catholic University of America Press.

(C) 2017 by the author. Licensee MDPI, Basel, Switzerland. This article is an open access article distributed under the terms and conditions of the Creative Commons Attribution (CC BY) license (http://creativecommons.org/licenses/by/4.0/). 